\title{
First record of Trichinella in Leopardus guigna (Carnivora, Felidae) and Galictis cuja (Carnivora, Mustelidae): New hosts in Chile
}

\author{
Diana Maritza Echeverry ${ }^{1}$, AnaLía Henríquez ${ }^{2}$, Pablo Oyarzún-Ruiz ${ }^{1}$, Maria Carolina Silva-de la Fuente ${ }^{3}$, Rene \\ Ortega $^{1}$, Daniel Sandoval ${ }^{1}$, Carlos Landaeta-Aqueveque ${ }^{\text {Corresp. } 1}$ \\ ${ }^{1}$ Facultad de Ciencias Veterinarias, Universidad de Concepción, Chillán, Región de Biobío/Ñuble, Chile \\ 2 Facultad de Medicina Veterinaria, Universidad San Sebastián, Concepción, Biobío, Chile \\ 3 Facultad de Ciencias Veterinarias, Universidad Austral de Chile, Valdivia, Los Ríos, Chile \\ Corresponding Author: Carlos Landaeta-Aqueveque \\ Email address: clandaeta@udec.cl
}

Background. Trichinellosis is a zoonotic disease with a worldwide distribution. It is caused by several species of nematodes in the genus Trichinella. Trichinella spp. are transmitted through predation or carrion consumption and occur in domestic and sylvatic cycles. In humans trichinellosis occurs due to the consumption of raw or undercooked, infected meat and is mainly associated with the household slaughter of pigs or the consumption of game animals without veterinary inspection, a cultural practice that is difficult to resolve. Therefore, knowledge of this parasite's reservoir is relevant for better implementing public health strategies. The aim of this study was to assess the presence of Trichinella sp. in several carnivore and omnivore vertebrates in central-southern Chile.

Methods. We collected muscle tissue from a total of 53 animals from 15 species and were digested to detect Trichinella larvae which were further identified to species level using molecular techniques.

Results. We detected Trichinella larvae in Leopardus guigna (Felidae) and Galictis cuja (Mustelidae). We identified the larvae collected from L. guigna as Trichinella spiralis, but we were unable to molecularly characterize the larvae from G. cuja. This is the first record of Trichinella in a native mustelid of South America and the first record of $T$. spiralis in L. guigna. This study identified two novel hosts; however, further work is needed to identify the role that these and other hosts play in the cycle of Trichinella in Chile. 
1 First record of Trichinella in Leopardus guigna (Carnivora, 2 Felidae) and Galictis cuja (Carnivora, Mustelidae): New

\section{3 hosts in Chile}

4

5 Diana M. Echeverry ${ }^{1}$, AnaLía Henríquez ${ }^{2}$, Pablo Oyarzún-Ruiz ${ }^{1}$, María C. Silva-de la Fuente ${ }^{3}$,

6 René Ortega $^{1}$, Daniel Sandoval ${ }^{1}$, Carlos Landaeta-Aqueveque ${ }^{1}$

7

$8 \quad{ }^{1}$ Facultad de Ciencias Veterinarias, Universidad de Concepción, Chillán, Chile.

$9 \quad{ }^{2}$ Facultad de Medicina Veterinaria, Universidad San Sebastián, Concepción, Chile.

$10{ }^{3}$ Facultad de Ciencias Veterinarias, Universidad Austral de Chile, Valdivia, Chile.

11

12 Corresponding Author:

13 Carlos Landaeta-Aqueveque ${ }^{1}$

14 Vicente Méndez 595, Chillán, Zip code 38121, Chile.

15 Email address: clandaeta@udec.cl 


\section{Abstract}

18 Background. Trichinellosis is a zoonotic disease with a worldwide distribution. It is caused by several species of nematodes in the genus Trichinella. Trichinella spp. are transmitted through predation or carrion consumption and occur in domestic and sylvatic cycles. In humans trichinellosis occurs due to the consumption of raw or undercooked, infected meat and is mainly associated with the household slaughter of pigs or the consumption of game animals without veterinary inspection, a cultural practice that is difficult to resolve. Therefore, knowledge of this parasite's reservoir is relevant for better implementing public health strategies. The aim of this study was to assess the presence of Trichinella sp. in several carnivore and omnivore vertebrates in central-southern Chile.

Methods. We collected muscle tissue from a total of 53 animals from 15 species and were digested to detect Trichinella larvae which were further identified to species level using molecular techniques.

Results. We detected Trichinella larvae in Leopardus guigna (Felidae) and Galictis cuja (Mustelidae). We identified the larvae collected from L. guigna as Trichinella spiralis, but we were unable to molecularly characterize the larvae from G. cuja. This is the first record of Trichinella in a native mustelid of South America and the first record of T. spiralis in L. guigna. This study identified two novel hosts; however, further work is needed to identify the role that these and other hosts play in the cycle of Trichinella in Chile.

\section{Introduction}

Trichinellosis is a disease that is distributed worldwide and is caused by nematodes in the genus Trichinella (Korhonen et al., 2016). It is considered neglected and emerging in some regions (Dupouy-Camet, 1999; Murrell \& Pozio, 2000; Bruschi, 2012; Boutsini et al., 2014). Trichinella nematodes are transmitted from animals to humans by the ingestion of raw or undercooked infected meat.

Trichinella is transmitted among non-human animals via predation and carrion consumption; therefore, it circulates among carnivorous and omnivorous vertebrates. Two cycles have been described: the domestic (encompassing mainly pigs, rats, dogs, and cats) and the sylvatic (encompassing free-range vertebrates) cycles (Pozio, 2000; Pozio, 2007; Loutfy et al., 1999). These cycles can be connected and fed back by invasive rats and other synanthropic animals (Pozio, 2000). The domestic cycle was the primary cause of human infections; however, improvements in pork production have reduced outbreaks globally (Devleesschauwer et al., 2015; Murrell, 2016). The improvements to pork production changed the epidemiology of trichinellosis in human populations. Trichinella infections now primarily occur during the consumption of meat from unregulated sources, mainly backyard pork production and the consumption of game animals (Pozio, 2014; Tryland et al., 2014; Fichi et al., 2015; Kärssin et al., 2017).

At present, there are 10 recognized species of Trichinella around the world and three additional genotypes that have not yet been identified as distinct species (Korhonen et al., 2016; Sharma et 
57 al., 2020). Most species infect only mammals (Klun et al., 2019; Bilska-Zajac et al., 2020),

58

59

60

61

62

63

64

65

66

67

68

69

70

71

72

73

74

75

76

77

78

79

80

81

82

83

84

85

86

87

88

89

90

91

92

93

94

95

96 including marine mammals (Tryland et al., 2014; Pasqualetti et al., 2018). However, Trichinella pseudospiralis Garkavi, 1972 also infects birds, and Trichinella zimbabwensis Pozio et al., 2002 and Trichinella papuae Pozio et al., 1999 infect reptile hosts (Korhonen et al., 2016). Thus, obtaining ecological and epidemiological knowledge of the transmission cycle is relevant for reducing the incidence of this parasite.

In South America, Trichinella spp. infections have been detected in Argentina, Bolivia, Chile (larvae isolation), Brazil, and Ecuador (antibody detection) with most studies focusing on the domestic cycle (Bjorland et al., 1993; Ribicich et al., 2020). Four species have been reported: Trichinella spiralis Owen, 1835, Trichinella patagoniensis Krivokapich et al. 2012, Trichinella britovi Pozio et al. 1992, and T. pseudospiralis (Krivokapich et al., 2006; Krivokapich et al., 2012; Krivokapich et al., 2015; Krivokapich et al., 2019). Additionally, Trichinella infections have been documented from eight wild species: cougar (Puma concolor Linnaeus, 1771), wild boar (Sus scrofa Linnaeus, 1758), fox (Lycalopex gymnocercus gracilis Fischer, 1814), opossum (Didelphis albiventris Lund, 1840), sea lion (Otaria flavescens Shaw, 1800), pecarí (Tayassu tajacu Palmer, 1897), armadillo (Chaetophractus villosus Desmerest, 1804), and pericote (Graomys centralis Thomas, 1902) (Minoprio, Abdon \& Abdon, 1967; Ribicich et al., 2020; Soria et al., 2010).

In Chile, the domestic cycle is fairly well-studied (Alcaino \& Arenas, 1981; Schenone et al., 2002), but the sylvatic cycle is largely unknown. Trichinella spiralis is the sole species that has been reported in Chile (Schenone et al., 2002; Landaeta-Aqueveque et al., 2015; Hidalgo et al., 2019; Echeverry et al., 2021; Espinoza-Rojas et al., 2021). Among non-domestic animals, cougars, American minks (Neovison vison Schreber, 1777) and wild boar are the only wild/feral hosts with documented infections (Landaeta-Aqueveque et al., 2015; Hidalgo et al., 2019; Echeverry et al., 2021; Espinoza-Rojas et al., 2021). In addition to those reports, other studies have not found infected animals (Alvarez et al., 1970; González-Acuña et al., 2010; RamirezPizarro et al., 2019). Therefore, the objective of this study was to assess the presence of Trichinella sp. in carnivorous and omnivorous wild vertebrates from south-central Chile.

\section{Materials \& Methods}

The study area includes four administrative regions of Chile: the O'Higgins, Maule, Nuble, and Biobío regions (Figure 1). These regions feature a transitional climate that falls somewhere between the classifications of warm Mediterranean (Csb, after Köpen classification) and wet temperate oceanic ( $\mathrm{Cfb}$, after Köpen classification). These regions lie within the limits between central and southern Chile.

This study considered animals that were found dead, mainly run over by a vehicle, or that died in wild animal rescue/rehabilitation centers (Fauna Rehabilitation Center of the Universidad de Concepción; Wild Fauna Rehabilitation Center of the Universidad San Sebastián) from 2013 to 2020. We examined at least $1 \mathrm{~g}$ of muscle (10 g, when possible) of these animals to determine the presence of Trichinella spp. larvae. We then selected the following muscles for

Peer] reviewing PDF | (2021:01:57288:3:0:NEW 17 May 2021) 
97 parasitological examination: the diaphragm, masseter, tongue, quadriceps (in mammals), pectoral 98 (in birds), and intercostals (in all animals).

99 We performed artificial digestion of the muscles following the method described by Gajadhar et 100 al. (2019) and preserved the larvae in 96\% ethanol. For molecular identification, we extracted 101 DNA from a pool of 10 Trichinella larvae isolated from each positive animal using the DNeasy 102 Blood \& Tissue Kit (Qiagen, Hilden, Germany) and used 10 ng of DNA for identification at the

103

104

105

106

107

108

109

110

111

112

113

114

115

116

117

118

119

120

121

122

123

124

125

126

127

128

129

130

131

132

133

134

135

136 species level by nested polymerase chain reaction (PCR), following a modification of the protocol of Zarlenga et al. (1999). We performed the reactions at a final volume of $25 \mu \mathrm{L}$. We used the following primers: $\mathrm{Ne}$ forward (5'-TCTTGGTGGTAGTAGC-3') and reverse (5'GCGATTGAGTTGAACGC-3') in the first PCR ( $0.5 \mu \mathrm{M}$ of each primer), and $12.5 \mu \mathrm{L}$ of GoTaq Green Master Mix (Promega Corporation, Madison, WI, USA). We amplified the DNA in a thermocycler (MultiGene ${ }^{\mathrm{TM}}$ OptiMax Thermal Cycler; Labnet International, Inc., Edison, NJ, USA) under the following cycling conditions: $95^{\circ} \mathrm{C} \times 1$ minute for initial denaturation, followed by 40 cycles of $95^{\circ} \mathrm{C} \times 30 \mathrm{sec} ; 56^{\circ} \mathrm{C} \times 1$ minute, and $72^{\circ} \mathrm{C} \times 1$ minute; and a final extension of $72^{\circ} \mathrm{C} \times 2$ minutes. Then, we used $0.5 \mu \mathrm{M}$ of each Primers $I$ forward (5'GTTCCATGTGAACAGCAG-3') and reverse (5'- CGAAAACATACGACAACTGC-3') in a second PCR under same conditions with an annealing temperature of $55^{\circ} \mathrm{C}$. The PCR products were subjected to electrophoresis in $2 \%$ agarose gel. We used master mix without the DNA as the negative control, and T. spiralis larvae obtained from a previous study (Landaeta-Aqueveque et al., 2015) as a positive control of the PCR.

Bioethical considerations: This study met the International Guiding Principles for Biomedical Research Involving Animals. The Comité de Ética of the Facultad de Ciencias Veterinarias of the Universidad de Concepción approved the study (CBE-47-2017).

\section{Results}

We collected samples from 53 animals. The sample was composed of 28 mammals, 24 birds and one reptile (Table 1). The weight of the examined muscle samples were at least $10 \mathrm{~g}$ with the exception of $D$. bozinovici and $P$. chamissonis with samples sizes of $3 \mathrm{~g}$ and $1 \mathrm{~g}$, respectively. Trichinella larvae were isolated only from one Leopardus guigna Molina, 1782 (güiña; 52 larvae per gram of muscle) and one Galictis cuja Molina, 1782 (lesser grison; 0.3 larvae per gram of muscle), both from the Ñuble region (Figure 1). We were unable to amplify DNA from the larvae isolated from the grison. However, we were able to amplify a PCR product of $173 \mathrm{bp}$ from the güiña which is consistent with our T. spiralis positive control (Figure 2) and the size described for this species (Pozio \& Zarlenga, 2019).

\section{Discussion}

Detecting Trichinella infection is a challenge in wild fauna of Chile because most carnivore vertebrates are protected by law $(S A G, 2012)$. This protection is due to conservation concerns or because these animals aid in pest control. Therefore, only invasive animals can be hunted to assess Trichinella infection (Hidalgo et al., 2019; Ramirez-Pizarro et al., 2019; Espinoza-Rojas 
137 et al., 2021). This has resulted in few studies that have assessed the presence of Trichinella 138 infection in native wildlife in Chile (Alvarez et al. 1970; González-Acuña et al. 2010; Hidalgo et 139 al., 2013; Landaeta-Aqueveque et al., 2015; Echeverry et al., 2021). Although one of these 140 studies sampled a broad range of mammalian species including güiñas and lesser grisons, it did not detect Trichinella spp. (Alvarez et al. 1970).

142 Studies in Argentina examined another wild felid, the Geoffroy's cat (Leopardus geoffroyi D' 143 Orbigny and Gervais, 1844), and the lesser grison with negative results (Ribicich et al., 2010; 144 Winter et al., 2018). Thus, this is the first record of Trichinella spp. larvae in a native mustelid in 145 South America, and the first record of T. spiralis in the güiña. The güiña is the second reported 146 South American felid host for this species.

147 Previously, other mustelids have been reported to host Trichinella infections: American mink 148 infected with $T$. spiralis in Chile (Espinoza-Rojas et al., 2021) and with T. spiralis, T. britovi, 149 and T. pseudospiralis in Poland (Hurniková et al., 2016) and the European badger (Meles meles 150 Linnaeus, 1758) infected with T. britovi in Romania (Boros et al., 2020). Similarly, other felids

151

152

153

154

155

156

157

158

159

160

161

162

163

164

165

166

167

168

169

170

171

172

173

174

175

176 have reportedly harbored Trichinella larvae. Trichinella infections have been reported in cougars across most of their range including with T. spiralis in Chile (Landaeta-Aqueveque et al., 2015; Echeverry et al., 2021), T. patagoniensis in Argentina (Krivokapich et al., 2012), T. spiralis and T. pseudospiralis in the United States (Reichard et al., 2015), Trichinella nativa Britov and Boev, 1972, T. pseudospiralis, Trichinella murrelli Pozio and La Rosa, 2000, and Trichinella T6 in Canada (Gajadhar \& Forbes, 2010). Additionally, infections have been reported in Canadian lynx (Lynx canadensis Kerr, 1792) with Trichinella T6 in Canada (Gajadhar \& Forbes, 2010), Eurasian lynx (Lynx lynx Schreber, 1777) with T. britovi, and the European wildcat (Felis silvestris Schreber, 1777) with T. britovi and T. spiralis (Pozio et al., 2009).

The güiña is one of the smallest felids in the world. It is distributed across Chile and Argentina between latitudes of $33^{\circ} \mathrm{S}$ and $48^{\circ} \mathrm{S}$ (Napolitano et al., 2014). This felid consumes micromammals such as rodents as primary prey (Delibes-Mateos et al., 2014; Figueroa, Corales \& Rau, 2018); consequently, rodents could be the source of infection. Rodents have been recognized as hosts of $T$. spiralis, mainly in the domestic environment in Chile (Schenone et al., 1967; Schenone et al., 2002). This record is in accordance with the fact that güiñas have been frequently infected by pathogens from free-roaming domestic animals (Ortega et al., 2020; Sacristán et al., 2020); although $T$. spiralis is not an important pathogen for the health of nonhuman animals, its presence in the güiña highlights the need for pathogen surveillance in the rural-sylvatic interphase.

The lesser grison is a neotropical mustelid that inhabits an area spanning southern Peru, Uruguay, and Paraguay to southern Chile and Argentina, encompassing several environments (Prevosti \& Travaini, 2005). It is a generalist predator and rodents comprise an important part of its diet (Ebensperger, Mella \& Simonetti, 1991; Zapata et al., 2005). Given that, and considering how other pathogens have spilled from domestic animals (Megid et al., 2013; Pedrassani et al., 2018), this species might most likely be infected in domestic environments. However, identification of the Trichinella species harbored by the lesser grison helps to better understand 
177 the source of infection, given that not all Trichinella species identified in South America have 178 been reported in the domestic cycle. For instance, T. patagoniensis has been reported only in 179 cougars (Krivokapich et al., 2008; Krivokapich et al., 2012).

180 To the best of our knowledge, there are no reports of the güiña as prey of larger predators, 181 whereas the lesser horned owl (Bubo magellanicus) is the sole predator to be reported for the 182 lesser grison (Prevosti \& Travaini, 2005). In that respect, T. pseudospiralis, also zoonotic, is the 183 only species of the genus that has reportedly infected birds, and this may be the only species of 184 Trichinella that could be transmitted from the grison to the owl. However, this species has not 185 been reported in Chile and one record of a single pig from Argentina represents the only report in 186 South America (Krivokapich et al., 2015). Therefore, it is unlikely that this owl could play a role 187 in the sylvatic cycle of Trichinella in Chile. Hence, whether güiña and lesser grison participate in 188 the reservoir or constitute dead-end hosts is unknown, and the most likely way for Trichinella

189

190

191

192

193

194

195

196

197

198

199

200

201

202

203

204

205

206

207

208

209

210

211

212

213

214

215

larvae to be transmitted from these hosts seems to be their consumption by carrion-consuming mammals. Furthermore, human trichinellosis resulting from the direct consumption of a wild mammal has also been reported worldwide (García et al., 2005; Fichi et al., 2015); however, neither güiñas nor grisons are typical prey for hunters to eat, nor is their hunting permitted by law in Chile $(S A G, 2012)$. However, further studies are needed to evaluate these hypotheses. It is worth noting that the two types of mammal host species reported herein had the largest sample sizes, suggesting that larger samples of other mammals could represent new hosts for Trichinella. In contrast, the lack of findings identified by Alvarez et al. (1970) may have been due to the real absence of larvae in their samples, as well as to the parasitological technique (trichinoscopy) used, which is of lower sensitivity (Forbes, Parker \& Scandrett, 2003).

\section{Conclusions}

This is the first record of Trichinella larvae in a native mustelid, G. cuja, in South America, as well as the first record of T. spiralis in L. guigna. Thus, this study increased the number of mammals infected with Trichinella larvae in the neotropics, enhancing the need to identify the role played by neotropical animals in the reservoir for humans. This underlies how studying the rural-sylvatic interphase is of utmost importance.

\section{Acknowledgements}

In memoriam: The authors dedicate this article to Daniel González-Acuña, who died during the writing of this manuscript prior to submission, and who made significant contributions to this study.

\section{References}

Alcaíno HA, and Arenas X. 1981. Antecedentes sobre triquinosis en Chile. Monografias de Medicina Veterinaria 3. https://revistas.uchile.cl/index.php/MMV/article/view/4847/ 
216

217

218

219

220

221

222

223

224

225

226

227

228

229

230

231

232

233

234

235

236

237

238

239

240

241

242

243

244

245

246

247

248

249

250

251

252

253

254

255

256

257

258

259

260

261

Alvarez V, Rivera G, Neghme A, and Schenone H. 1970. Triquinosis en animales de Chile. Boletín Chileno de Parasitología 25:83-86.

Bilska-Zając E, Różycki M, Grądziel-Krukowska K, Bełcik A, Mizak I, Karamon J, Sroka J, Zdybel J, and Cencek T. 2020. Diversity of Trichinella species in relation to the host species and geographical location. Veterinary Parasitology 279:109052. 10.1016/j.vetpar.2020.109052

Bjorland J, Brown D, Ray Gamble H, and McAuley JB. 1993. Trichinella spiralis infection in pigs in the Bolivian Altiplano. Veterinary Parasitology 47:349-354. DOI: 10.1016/03044017(93)90036-M

Boros Z, Ionică AM, Deak G, Mihalca AD, Chisamera GB, Györke A, Gherman CM, and Cozma V. 2020. The European badger, Meles meles, as a new host for Trichinella britovi in Romania. Veterinary Parasitology 288:109301. 10.1016/j.vetpar.2020.109301

Boutsini S, Papatsiros VG, Stougiou D, Marucci G, Liandris E, Athanasiou LV, Papadoudis A, Karagiozopoulos E, Bisias A, and Pozio E. 2014. Emerging Trichinella britovi infections in free ranging pigs of Greece. Veterinary Parasitology 199:278-282.

10.1016/j.vetpar.2013.10.007

Bruschi F. 2012. Trichinellosis in developing countries: is it neglected? The Journal of Infection in Developing Countries 6:216-222. 10.3855/jidc.2478

Delibes-Mateos M, Díaz-Ruiz F, Caro J, and Ferreras P. 2014. Activity patterns of the vulnerable guiña (Leopardus guigna) and its main prey in the Valdivian rainforest of southern Chile. Mammalian Biology 79:393-397. 10.1016/j.mambio.2014.04.006

Devleesschauwer B, Praet N, Speybroeck N, Torgerson PR, Haagsma JA, De Smet K, Murrell KD, Pozio E, and Dorny P. 2015. The low global burden of trichinellosis: evidence and implications. International Journal for Parasitology 45:95-99.

10.1016/j.ijpara.2014.05.006

Dupouy-Camet J. 1999. Is human trichinellosis an emerging zoonosis in the European community? Helminthologia 36:201-204.

Ebensperger LA, Mella JE, and Simonetti JA. 1991. Trophic-Niche Relationships among Galictis cuja, Dusicyon culpaeus, and Tyto alba in Central Chile. Journal of Mammalogy 72:820-823. 10.2307/1381849

Echeverry DM, Santodomingo Santodomingo AM, Thomas RS, González-Ugás J, Oyarzún-Ruiz P, Silva-de la Fuente MC, and Landaeta-Aqueveque C. 2021. Trichinella spiralis in a cougar (Puma concolor) hunted by poachers in Chile. Revista Brasileira de Parasitologia Veterinária in press. 10.1590/S1984-29612021033

Espinoza-Rojas H, Lobos-Chávez F, Silva-de la Fuente MC, Echeverry DM, Muñoz-Galaz J, Yáñez-Crisóstomo C, Oyarzún-Ruiz P, Ortega R, Sandoval D, Henríquez A, Moreno Salas L, Acosta-Jamett G, and Landaeta-Aqueveque C. 2021. Survey of Trichinella in American minks (Neovison vison Schreber, 1777) and wild rodents (Muridae and Cricetidae) in Chile. Zoonoses and Public Health In press. 10.1111/zph.12845

Fichi G, Stefanelli S, Pagani A, Luchi S, De Gennaro M, Gómez-Morales MA, Selmi M, Rovai D, Mari M, Fischetti R, and Pozio E. 2015. Trichinellosis outbreak caused by meat from a wild boar hunted in an Italian region considered to be at negligible risk for Trichinella. Zoonoses and Public Health 62:285-291. 10.1111/zph.12148

Figueroa RA, Corales ES, and Rau JR. 2018. Prey of the güiña (Leopardus guigna) in an Andean mixed southern beech forest, southern Chile. Studies on Neotropical Fauna and Environment 53:211-218. 10.1080/01650521.2018.1477032

Peer] reviewing PDF | (2021:01:57288:3:0:NEW 17 May 2021) 
262

263

264

265

266

267

268

269

270

271

272

273

274

275

276

277

278

279

280

281

282

283

284

285

286

287

288

289

290

291

292

293

294

295

296

297

298

299

300

301

302

303

304

305

306

307
Forbes LB, Parker S, and Scandrett WB. 2003. Comparison of a modified digestion assay with trichinoscopy for the detection of Trichinella larvae in pork. Journal of Food Protection 66:1043-1046. 10.4315/0362-028x-66.6.1043

Gajadhar AA, and Forbes LB. 2010. A 10-year wildlife survey of 15 species of Canadian carnivores identifies new hosts or geographic locations for Trichinella genotypes T2, T4, T5, and T6. Veterinary Parasitology 168:78-83. 10.1016/j.vetpar.2009.10.012

Gajadhar AA, Noeckler K, Boireau P, Rossi P, Scandrett B, and Gamble HR. 2019. International Commission on Trichinellosis: Recommendations for quality assurance in digestion testing programs for Trichinella. Food and Waterborne Parasitology 16:e00059. 10.1016/j.fawpar.2019.e00059

García E, Mora L, Torres P, Jercic MI, and Mercado R. 2005. First record of human trichinosis in Chile associated with consumption of wild boar (Sus scrofa). Memórias do Instituto Oswaldo Cruz 100:17-18. 10.1590/S0074-02762005000100003

González-Acuña D, Moreno L, Ardiles K, Flores M, Duclos M, and Kinsella M. 2010. Endoparasites of the kodkod, Oncifelis guigna (Carnivora, Felidae) in Chile. Revista Chilena de Historia Natural 83:619-622. 10.4067/s0716-078x2010000400015

Hidalgo A, Oberg CA, Fonseca-Salamanca F, and Vidal MF. 2013. Report of the first finding of puma (Puma concolor puma) infected with Trichinella sp. in Chile. Archivos de Medicina Veterinaria 45:203-206. 10.4067/S0301-732X2013000200013

Hidalgo A, Villanueva J, Becerra V, Soriano C, Melo A, and Fonseca-Salamanca F. 2019. Trichinella spiralis Infecting Wild Boars in Southern Chile: Evidence of an Underrated Risk. Vector-Borne and Zoonotic Diseases 19:625-629. 10.1089/vbz.2018.2384

Hurníková Z, Kołodziej-Sobocińska M, Dvorožňáková E, Niemczynowicz A, and Zalewski A. 2016. An invasive species as an additional parasite reservoir: Trichinella in introduced American mink (Neovison vison). Veterinary Parasitology 231:106-109. 10.1016/j.vetpar.2016.06.010

Kärssin A, Häkkinen L, Niin E, Peik K, Vilem A, Jokelainen P, and Lassen B. 2017. Trichinella spp. biomass has increased in raccoon dogs (Nyctereutes procyonoides) and red foxes (Vulpes vulpes) in Estonia. Parasites \& Vectors 10. 10.1186/s13071-017-2571-0

Klun I, Ćosić N, Ćirović D, Vasilev D, Teodorović V, and Djurković-Djaković O. 2019. Trichinella spp. in wild mesocarnivores in an endemic setting. Acta Veterinaria Hungarica 67:34-39. 10.1556/004.2019.004

Korhonen PK, Pozio E, La Rosa G, Chang BCH, Koehler AV, Hoberg EP, Boag PR, Tan P, Jex AR, Hofmann A, Sternberg PW, Young ND, and Gasser RB. 2016. Phylogenomic and biogeographic reconstruction of the Trichinella complex. Nature Communications 7:10513. 10.1038/ncomms 10513

Krivokapich SJ, Gatti GM, Prous CLG, Degese MF, Arbusti PA, Ayesa GE, Bello GV, and Salomon MC. 2019. Detection of Trichinella britovi in pork sausage suspected to be implicated in a human outbreak in Mendoza, Argentina. Parasitology International 71:53-55. 10.1016/j.parint.2019.03.010

Krivokapich SJ, Gonzalez Prous CL, Gatti GM, and Saldia L. 2015. First finding of Trichinella pseudospiralis in the Neotropical region. Veterinary Parasitology 208:268-271. 10.1016/j.vetpar.2015.01.001

Krivokapich SJ, Molina V, Bergagna HFJ, and Guarnera EA. 2006. Epidemiological survey of Trichinella infection in domestic, synanthropic and sylvatic animals from Argentina. Journal of Helminthology 80:267-269. 10.1079/JOH2006338

PeerJ reviewing PDF | (2021:01:57288:3:0:NEW 17 May 2021) 
308

309

310

311

312

313

314

315

316

317

318

319

320

321

322

323

324

325

326

327

328

329

330

331

332

333

334

335

336

337

338

339

340

341

342

343

344

345

346

347

348

349

350

351

352

Krivokapich SJ, Pozio E, Gatti GM, Gonzalez Prous CL, Ribicich M, Marucci G, La Rosa G, and Confalonieri V. 2012. Trichinella patagoniensis n. sp. (Nematoda), a new encapsulated species infecting carnivorous mammals in South America. International Journal for Parasitology 42:903-910. 10.4067/S0716-078X2012000200009

Krivokapich SJ, Prous CLG, Gatti GM, Confalonieri V, Molina V, Matarasso H, and Guarnera E. 2008. Molecular evidence for a novel encapsulated genotype of Trichinella from Patagonia, Argentina. Veterinary Parasitology 156:234-240. 10.1016/j.vetpar.2008.06.003

Landaeta-Aqueveque C, Krivokapich S, Gatti GM, Prous CG, Rivera-Buckle V, Martin N, Gonzalez-Acuna D, and Sandoval D. 2015. Trichinella spiralis parasitizing Puma concolor: first record in wildlife in Chile. Helminthologia 52:360-363. 10.1515/helmin2015-0057

Loutfy NF, Awad OM, El-Masry AG and Kandil GM. 1999. Study on rodents infestation in Alexandria and prevalence of Trichinella spiralis infection among them. Journal of the Egyptian Society of Parasitology 29(3):897-909. https://europepmc.org/article/med/12561929

Megid J, Teixeira CR, Cortez A, Heinemann MB, Antunes JMAP, Fornazari F, Rassy FB, and Richtzenhain LJ. 2013. Canine distemper virus infection in a lesser grison (Galictis cuja): first report and virus phylogeny. Pesquisa Veterinária Brasileira 33:247-250. 10.1590/s0100-736x2013000200018

Minoprio JL, Abdon H, and Abdon D. 1967. Factores epidemiológicos que determinan la trichiniasis silvestre en el oeste de San Luis y en el este de Mendoza. Anales de la Sociedad Científica Argentina 183:19-30. https://ia801302.us.archive.org/20/items/analesdelaso183121967soci/analesdelaso183121 967soci.pdf

Murrell KD. 2016. The dynamics of Trichinella spiralis epidemiology: Out to pasture? Veterinary Parasitology 231:92-96. 10.1016/j.vetpar.2016.03.020

Murrell KD, and Pozio E. 2000. Trichinellosis: the zoonosis that won't go quietly. International Journal for Parasitology 30:1339-1349. 10.1016/S0020-7519(00)00132-6

Napolitano C, Johnson WE, Sanderson J, O’Brien SJ, Rus Hoelzel A, Freer R, Dunstone N, Ritland K, Ritland CE, and Poulin E. 2014. Phylogeography and population history of Leopardus guigna, the smallest American felid. Conservation Genetics 15:631-653. 10.1007/s10592-014-0566-3

Ortega R, Mena J, Grecco S, Pérez R, Panzera Y, Napolitano C, Zegpi NA, Sandoval A, Sandoval D, González-Acuña D, Cofré S, Neira V, and Castillo-Aliaga C. 2020. Domestic dog origin of Carnivore Protoparvovirus 1 infection in a rescued free-ranging guiña (Leopardus guigna) in Chile. Transboundary and Emerging Diseases. 10.1111/tbed.13807

Pasqualetti MI, Fariña FA, Krivokapich SJ, Gatti GM, Daneri GA, Varela EA, Lucero S, Ercole ME, Bessi C, Winter M, and Ribicich MM. 2018. Trichinella spiralis in a South American sea lion (Otaria flavescens) from Patagonia, Argentina. Parasitology Research 117:4033-4036. 10.1007/s00436-018-6116-z

Pedrassani D, Worm M, Drechmer J, and Santos MCI. 2018. Lesser Grison (Galictis cuja Molina, 1782) as host of Dioctophyme renale Goeze, 1782. Arquivos do Instituto Biológico 84:e0312016. 10.1590/1808-1657000312016 
353

354

355

356

357

358

359

360

361

362

363

364

365

366

367

368

369

370

371

372

373

374

375

376

377

378

379

380

381

382

383

384

385

386

387

388

389

390

391

392

393

394

395

396

397

398

Pozio E. 2000. Factors affecting the flow among domestic, synanthropic and sylvatic cycles of Trichinella. Veterinary Parasitology 93:241-262. 10.1016/S0304-4017(00)00344-7

Pozio E. 2007. World distribution of Trichinella spp. infections in animals and humans. Veterinary parasitology 149(1-2), 3-21. 10.1016/j.vetpar.2007.07.002

Pozio E. 2014. Searching for Trichinella: not all pigs are created equal. Trends in Parasitology 30:4-11. 10.1016/j.pt.2013.11.001

Pozio E, Rinaldi L, Marucci G, Musella V, Galati F, Cringoli G, Boireau P, and La Rosa G. 2009. Hosts and habitats of Trichinella spiralis and Trichinella britovi in Europe. International Journal for Parasitology 39:71-79. 10.1016/j.ijpara.2008.06.006

Pozio E, and Zarlenga D. 2019. International Commission on Trichinellosis: Recommendations for genotyping Trichinella muscle stage larvae. Food and Waterborne Parasitology 15:e00033. 10.1016/j.fawpar.2018.e00033

Prevosti FJ, and Travaini A. 2005. New records of Galictis cuja (Molina, 1782) (Carnivora, Mustelidae) in Southern Patagonia. Mammalian Biology 70:317-320. 10.1016/j.mambio.2005.03.004

Ramirez-Pizarro F, Silva-de la Fuente C, Hernandez-Orellana C, Lopez J, Madrid V, Fernandez I, Martin N, Gonzalez-Acuna D, Sandoval D, Ortega R, and Landaeta-Aqueveque C. 2019. Zoonotic Pathogens in the American Mink in Its Southernmost Distribution. Vector-Borne and Zoonotic Diseases 19:908-914. 10.1089/vbz.2019.2445

Reichard MV, Criffield M, Thomas JE, Paritte JM, Cunningham M, Onorato D, Logan K, Interisano M, Marucci G, and Pozio E. 2015. High prevalence of Trichinella pseudospiralis in Florida panthers (Puma concolor coryi). Parasites \& Vectors 8:67. 10.1186/s13071-015-0674-z

Ribicich M, Gamble HR, Bolpe J, Scialfa E, Krivokapich S, Cardillo N, Betti A, Cambiaggi Holzmann M, Pasqualetti M, Fari $\tilde{A} \pm$ a F, and Rosa A. 2010. Trichinella infection in wild animals from endemic regions of Argentina. Parasitology Research 107:377-380. DOI: 10.1007/s00436-010-1873-3

Ribicich MM, Fariña FA, Aronowicz T, Ercole ME, Bessi C, Winter M, and Pasqualetti MI. 2020. A review on Trichinella infection in South America. Veterinary Parasitology 285:109234. 10.1016/j.vetpar.2020.109234

Sacristán I, Esperón F, Pérez R, Acuña F, Aguilar E, García S, López MJ, Neves E, Cabello J, Hidalgo-Hermoso E, Terio KA, Millán J, Poulin E, and Napolitano C. 2020. Epidemiology and molecular characterization of Carnivore protoparvovirus-1 infection in the wild felid Leopardus guigna in Chile. Transboundary and Emerging Diseases. 10.1111/tbed. 13937

SAG. 2012. Ley de Caza y su Reglamento. Available at http://www.sag.cl/sites/default/files/ley_caza edicion2012.pdf(accessed Dec 30 2014).

Schenone H, Jacob C, Rojas A, and Villarrel F. 1967. Infección por Trichinella spiralis en Rattus norvegicus capturados en el Matadero Municipal de Santiago. Boletín Chileno de Parasitología 22:176.

Schenone H, Olea A, Schenone H, Contreras M, Mercado R, Sandoval L, and Pavletic C. 2002. Situación epidemiológica actual de la triquinosis en Chile. 1991-2000. Revista médica de Chile 130:281-285. DOI: 10.4067/S0034-98872002000300006

Sharma R, Thompson PC, Hoberg EP, Brad Scandrett W, Konecsni K, Harms NJ, Kukka PM, Jung TS, Elkin B, Mulders R, Larter NC, Branigan M, Pongracz J, Wagner B, Kafle P, Lobanov VA, Rosenthal BM, and Jenkins EJ. 2020. Hiding in plain sight: discovery and

PeerJ reviewing PDF | (2021:01:57288:3:0:NEW 17 May 2021) 
phylogeography of a cryptic species of Trichinella (Nematoda: Trichinellidae) in wolverine (Gulo gulo). International Journal for Parasitology 50:277-287. 10.1016/j.ijpara.2020.01.003

Soria C, Mozo G, Camaño C, Saldaño B, López E, Malandrini J and Soria J. 2010. Isolation of Trichinella spp. larvae in peccary (Tayassu tajacu) of Icaño, Departament La Paz, Catamarca. Revista Electrónica Iberoamericana de Educación en Ciencias y Tecnología 2(1):153-163. http://www.exactas.unca.edu.ar/riecyt/VOL\%202\%20NUM\%201/Archivos\%20Digitales/ Doc\%20RIECyT\%20V2-1-9.pdf

Tryland M, Nesbakken T, Robertson L, Grahek-Ogden D, and Lunestad BT. 2014. Human pathogens in marine mammal meat - A Northern perspective. Zoonoses and Public Health 61:377-394. 10.1111/zph.12080

Winter M, Pasqualetti M, Fariña F, Ercole M, Failla M, Perello M, Birochio D, Abate S, Soricetti M, and Ribicich M. 2018. Trichinellosis surveillance in wildlife in northeastern argentine patagonia. Veterinary Parasitology: Regional Studies and Reports 11:32-35. 10.1016/j.vprsr.2017.11.009

Zapata SC, Travaini A, Delibes M, and Martínez-Peck R. 2005. Annual food habits of the lesser grison (Galictis cuja) at the southern limit of its range. Mammalia 69. 10.1515/mamm.2005.008

Zarlenga DS, Chute MB, Martin A, and Kapel CMO. 1999. A multiplex PCR for unequivocal differentiation of all encapsulated and non-encapsulated genotypes of Trichinella. International Journal for Parasitology 29:1859-1867. 10.1016/S0020-7519(99)00107-1 
Table $\mathbf{1}$ (on next page)

Details of examined animals 
1 Table 1: Details of examined animals.

\begin{tabular}{lrc} 
Species & Infected/Analyzed & \\
\hline Glaucidium nana King, 1828 (Austral pygmy owl) & $(\%)$ & Class \\
Bubo magellanicus Gmelin, 1788 (Magellanic horned owl) & $0 / 2(0)$ & Aves \\
Tyto furcata Temminck, 1827 (American barn owl) & $0 / 5(0)$ & Aves \\
Strix rufipes King, 1828 (Rufous-legged owl) & $0 / 2(0)$ & Aves \\
Parabuteo unicinctus Temminck, 1824 (Harris' hawk) & $0 / 11(0)$ & Aves \\
Coragyps atratus Bechstein, 1793 (Black vulture) & $0 / 1(0)$ & Aves \\
Cathartes aura Linnaeus, 1758 (Turkey vulture) & $0 / 1(0)$ & Aves \\
Pelecanus thagus Molina, 1782 (Peruvian pelican) & $0 / 1(0)$ & Aves \\
Grampus griseus Cuvier, 1812 (Risso's Dolphin) & $0 / 1(0)$ & Mammalia \\
Otaria flavescens Shaw, 1800 (South American sealion) & $0 / 1(0)$ & Mammalia \\
Leopardus guigna Molina, 1782 (Güiña) & $1 / 6(16.67)$ & Mammalia \\
Lycalopex culpaeus Molina, 1782 (Culpeo fox) & $0 / 2(0)$ & Mammalia \\
Galictis cuja Molina, 1782 (Lesser grison) & $1 / 17(5.88)$ & Mammalia \\
Dromiciops bozinovici D'Elía, Hurtado and D'Anatro, 2016 & $0 / 1(0)$ & Mammalia \\
('Monito del monte') & & \\
Philodryas chamissonis Wiegmann, 1834 (Long-tailed & $0 / 1(0)$ & Reptilia
\end{tabular}


Figure 1

Map of Chile (A) and the studied administrative regions (B).

The italicized text indicates the name of the regions, and the Roman text indicates the name of the communes. Infected animals are presented with the symbols "+" (Leopardus guigna) and "*" (Galictis cuja). The numbers indicate the number of animals examined in each commune. Thick lines indicate the regional limits, while thin lines indicate the limits of the communes.

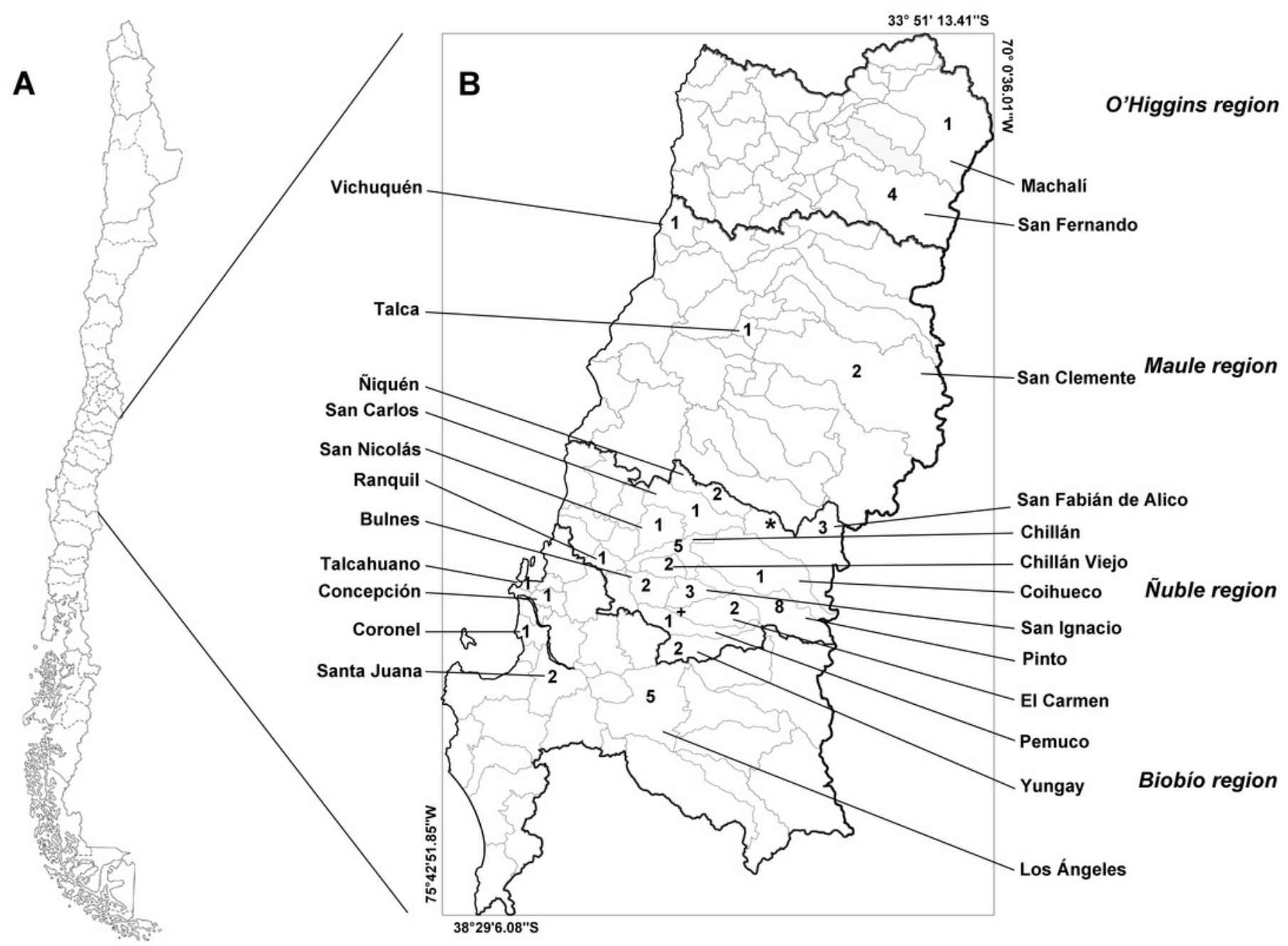


Figure 2

a) Larva of Trichinella sp. isolated from a Galictis cuja. b) Gel electrophoresis of PCR products

(b) MW: Marker of 50 bp. C-: negative control. C+: Trichinella spiralis positive control. Lanes 1

- 4: isolates from Leopardus guigna. 


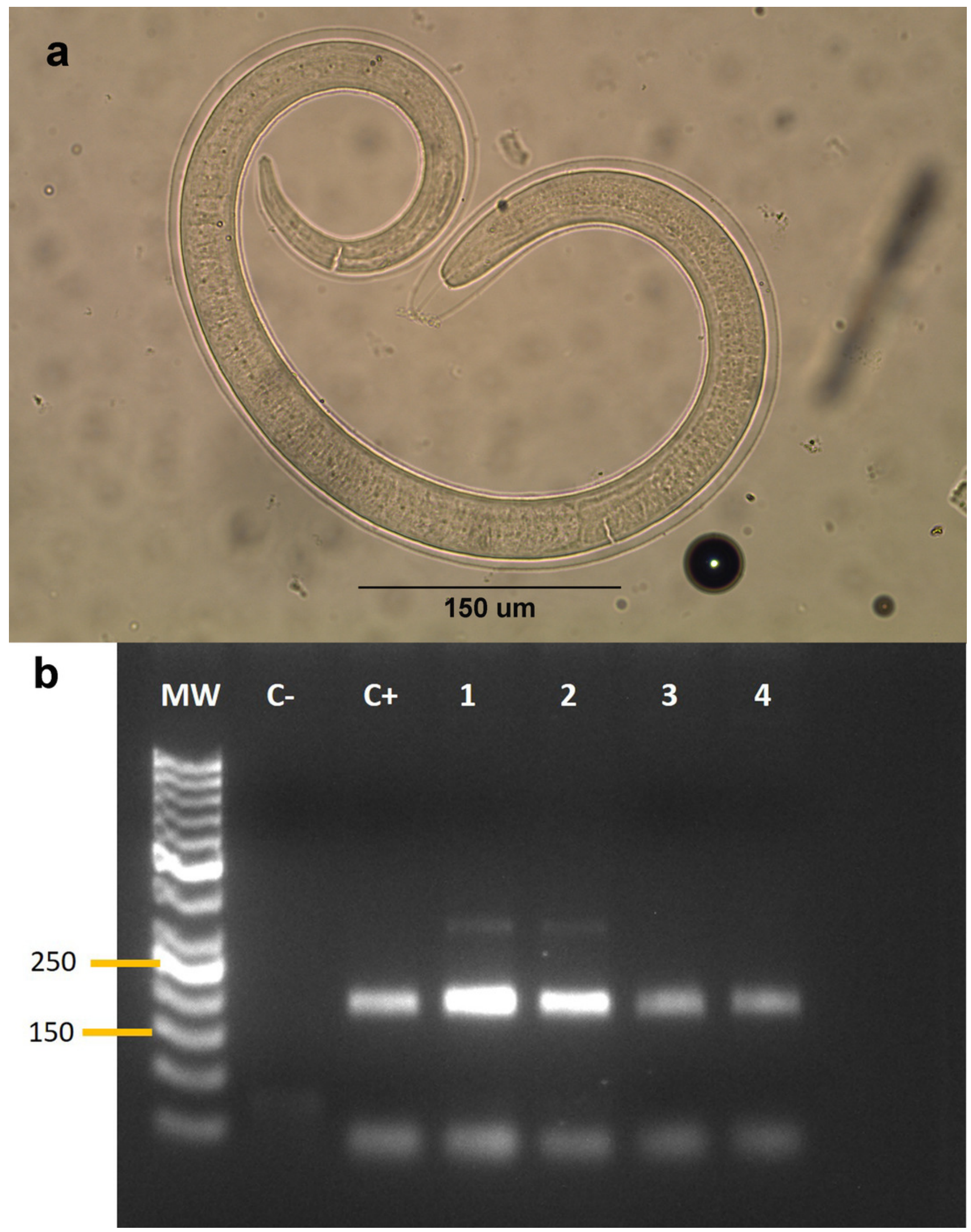

